\title{
DEREGULATION OF ELECTRICITY MARKET AND DRIVERS OF DEMAND FOR ELECTRICAL ENERGY IN INDUSTRY
}

\author{
Štefan Bojnec ${ }^{1}$, Drago Papler ${ }^{2}$ \\ ${ }^{1}$ University of Primorska, Faculty of Management, Slovenia \\ ${ }^{2}$ Electro Gorenjska, Slovenia \\ Corresponding author: \\ Stefan Bojnec \\ University of Primorska \\ Faculty of Management \\ Cankarjeva 5, SI-6104 Koper, Slovenia \\ phone: (+386 5) 610-20-46 \\ e-mail:stefan.bojnec@fm-kp.si; stefan.bojnec@siol.net
}

Received: 1 June 2016

Accepted: 1 July 2016

\begin{abstract}
This paper investigates deregulation of electricity market focusing on electricity prices and drivers of demand for electrical energy in industry in Slovenia. The patterns in evolution of real electricity price developments and the three main components of the electricity price are calculated: liberalized market share for purchased electricity price, regulated infrastructure share for use of electricity network grids and mandatory state charges in the sale of electricity (duty, excise duty and value-added tax). To calculate the real value of electricity prices, producer price index of industrial commodities for electricity prices in industry is used as deflator and implicit deflator of gross domestic product for the size of the economy. In the empirical econometric part is used regression analysis for the amount electricity consumption in the industry depending on the real gross domestic product, direct and cross-price elasticity for natural gas prices in the industry. The results confirmed volatility in real electricity price developments with their increasing tendency and the increasing share of different taxes and state charges in the electricity prices for industry. Demand for electrical energy in industry is positively associated with gross domestic product and price of natural gas as substitute for electrical energy in industry use, and negatively associated with prices of electrical energy for industry.
\end{abstract}

KEYWORDS

electricity prices, market deregulation, industrial users, demand function, Slovenia.

\section{Introduction}

The gradual deregulation and liberalisation of the electricity markets in Slovenia has been completed since mid-2007. The initial deregulation in Slovenia has started in 2001 with the liberalisation of the electricity market for the largest industrial users of electrical energy. The deregulation has followed in the mid-2004 for the other electricity users, except for households, and in the mid-2007 also for the households' electricity users [1-5]. The entry of new possible suppliers and freer trade with electrical energy, particularly possible import competition, might increase competitive pressures on electricity markets and contribute to the increased quality and price competition.
We investigate evolution in development of real prices of electrical energy for industry and their structures, and particularly determinants of electricity consumption by the industrial users in Slovenia. The structure of the industrial users of electrical energy is divided into the sixteen groups by the size of electrical energy consumption [6]. The greatest shares in the electrical energy consumption in industry are pertained to largest users between 70 and $150 \mathrm{GWh}$ and above $400 \mathrm{GWh}$. Among more important consumers of electrical energy in industry are also consumers or industrial enterprises, which belong to the size groups from 4 to $10 \mathrm{GWh}$ and from 150 to $400 \mathrm{GWh}$ of electrical energy consumption.

The electricity market deregulation and electricity price liberalisation have expected to encourage 
greater competition, which will force suppliers of electrical energy to more competitive supply and to creation of brand names $[4,7]$. On the basis of the methodology for monitoring of prices of electrical energy and natural gas (supplement to Directive 90/377/EC, 28 October 2008) [8], which is used for calculation of annual consumption of electrical energy, we analyse prices of user groups of electrical energy for industry. We focus on the analysis of real price developments, analysis of final price, analysis of costs and prices for use of electrical network grids, and analyse different taxes on electrical energy during the analysed years. Finally, we analyse demand for electricity consumption in industry with drivers of its determination. The focus is on demand function with included impact of deregulation on electricity market for industrial users or larger industrial enterprises. We employ the regression analysis to estimate consumption functions for industrial users $[9,10]$.

\section{Entry of new suppliers and the market shares at the local markets}

Since the electricity market deregulation and price liberalisation, the new suppliers have entered into the electricity markets. This has been reflected in the deterioration of the local regional supplier's market share, which have been taken by others nonlocal regional suppliers. For example in the case of industrial users, the Electro Gorenjska (ELGO) had the local market shares between $93.9 \%$ and $96.4 \%$ in 2006, but this has deteriorated between $88.7 \%$ and $93.3 \%$ in 2007 and later has been further deteriorated. Similar as for the ELGO, which is one of the electricity distribution enterprises in Slovenia also for other 5-distribution enterprises the shares are not substantially different. The distribution enterprises shares at the local markets varied between $83.4 \%$ and $88.8 \%$ in 2006 , and between $84.7 \%$ and $88.2 \%$ in 2007 [6].

Among the most often used measures for presentation of distribution of appearance differences are Lorenz curve and Gini coefficient of concentration. We use these measures to present distribution of relative frequency in the sale of electrical energy for industry in Slovenia, and particularly for the ELGO. The concentration of the electrical energy users in industry in Slovenia and thus also the supply of electrical energy to them, is very concentrated and rather stable between the individual years. Figure 1 confirms that the concentration of the Slovenian electricity users in industry is rather concentrated by individual electrical energy suppliers: ELGO, distri- bution enterprises and other suppliers as well as for all suppliers. In the case of the ELGO $15 \%$ of industrial users consume around $83 \%$ of their electricity supply to industry, while in the case of the distribution enterprises in Slovenia $40 \%$ of industrial users consume around $98 \%$ of their electricity supply to industry. The Lorenz curve for the group of other electricity suppliers shows the highest concentration of their industrial users; the Lorenz curve moves toward the right-hand side bottom corner: $5 \%$ of industrial users consume $93 \%$ of their electricity supply to industry. In the case of total electricity supply to industrial users by all suppliers in Slovenia, their industrial users' concentration is between the first group of suppliers (ELGO and 5-distribution enterprises) and second group of suppliers (other suppliers) as clearly confirmed by the Lorenz curve: $10 \%$ of industrial users consume $82 \%$ of their electricity supply or $20 \%$ of industrial users consume $94 \%$ of their electricity supply to industry.

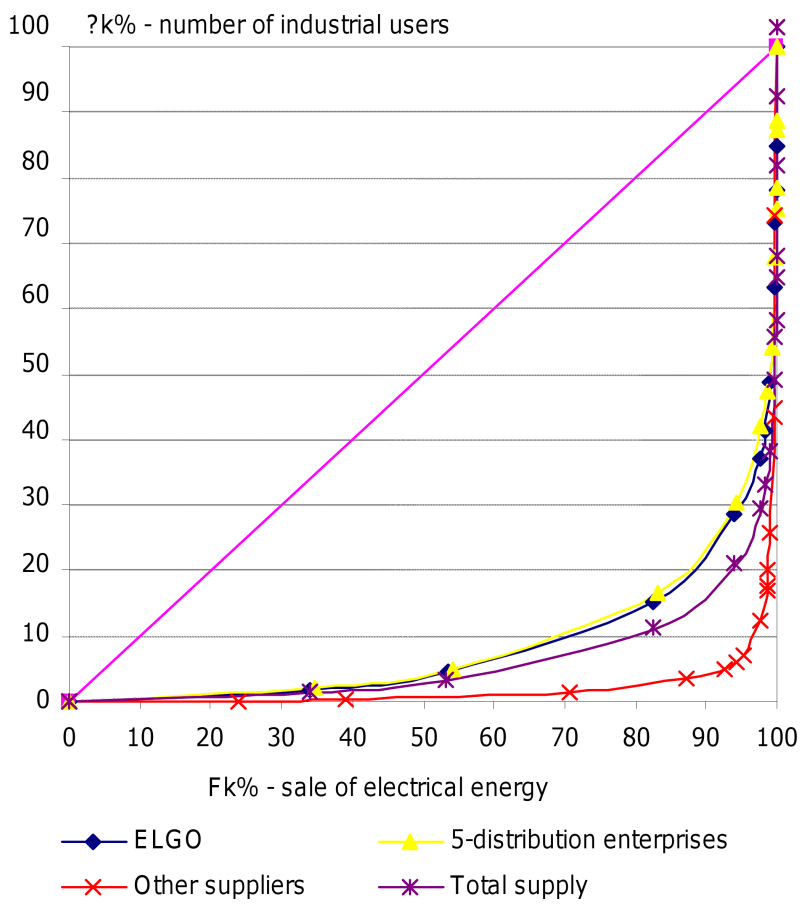

Fig. 1. Lorenz curve for concentration of industrial users of electrical energy by electricity suppliers in Slovenia, 2008.

The Gini coefficient of concentration of the industrial users of electrical energy in 2008 by the electrical energy suppliers confirms high concentration of industrial users by individual electricity suppliers: for the ELGO $G=0.83091$, for the 5-distribution enterprises $G=0.81588$, for other suppliers $G=$ 0.95844 and for the all suppliers of electrical energy to industry in Slovenia $G=0.87212$. High de- 
gree of concentration of the industrial users of electrical energy in Slovenia was with some variations over time.

\section{Groups of consumers of electrical energy in industry}

Prices of electrical energy for industry are calculated on the basis of the Information centre for uniform collection of data for needs of Ministry of Economy, Directorate for energy in Slovenia [11]. Prices are calculated on the basis of methodology [12], which is described in Directive 2008/92/ES and supplement of Directive 90/377/EC [13] of European Parliament and uniform procedure of the European Union (EU) for a greater transparency of prices of natural gas and electrical energy for industry. As can be seen from Table 1, there are six consumer groups of electrical energy for industry: IA, IB, IC, ID, IE and IF. They are defined on the basis of the interval of annual consumption of electricity.

Table 1

Standard consumer groups of electrical energy for industry.

\begin{tabular}{c|c|l}
\hline Symbol & $\begin{array}{c}\text { Annual } \\
\text { electricity } \\
\text { consumption }\end{array}$ & \multicolumn{1}{|c}{ Description } \\
\hline IA & $<20 \mathrm{MWh}$ & $\begin{array}{l}\text { Annual consumption } \\
\text { less than 20 MWh }\end{array}$ \\
\hline IB & $20<500 \mathrm{MWh}$ & $\begin{array}{l}\text { Annual consumption } \\
\text { from MWh to less than } \\
500 \text { MWh }\end{array}$ \\
\hline IC & $500<2000 \mathrm{MWh}$ & $\begin{array}{l}\text { Annual consumption } \\
\text { from 500 MWh to less } \\
\text { than 2000 MWh }\end{array}$ \\
\hline ID & $2000<20000 \mathrm{MWh}$ & $\begin{array}{l}\text { Annual consumption } \\
\text { from 2000 MWh to } \\
\text { less than 20000 MWh }\end{array}$ \\
\hline IE & $20000<70000 \mathrm{MWh}$ & $\begin{array}{l}\text { Annual consumption } \\
\text { from 20 000 MWh to } \\
\text { less than 70 000 MWh }\end{array}$ \\
\hline IF & $70000<150000 \mathrm{MWh}$ & $\begin{array}{l}\text { Annual consumption } \\
\text { from 70 000 MWh to } \\
\text { less than 150000 MWh }\end{array}$ \\
\hline
\end{tabular}

Note: Groups from IA to IF are defined on the basis of the interval in the annual electricity consumption.

Source: SORS [11].

\section{Price development}

The Statistical Office of the Republic of Slovenia [11] according to the Eurostat [12] methodology collects data on electricity prices for six typical different categories of industrial users: $I a, I b, I c, I d, I e$, If, and Ig. To calculate the real value of electricity prices for user groups in industry, electricity prices over time are deflated by the producer price index of industrial commodities for electricity prices in industry.

As can be seen from Fig. 2, the initial liberalisation of the electricity prices for industrial users caused the real price decline particularly for the industrial users on the low voltage with annual use $50 \mathrm{MWh}(\mathrm{Ib})$ and for the middle voltage with annual use $24000 \mathrm{MWh}(I g)$. After the initial decline, since 2005, the real electricity prices for industrial users have started to rise up to 2009, but they were at the lower level than they were before the liberalisation in 2001 .

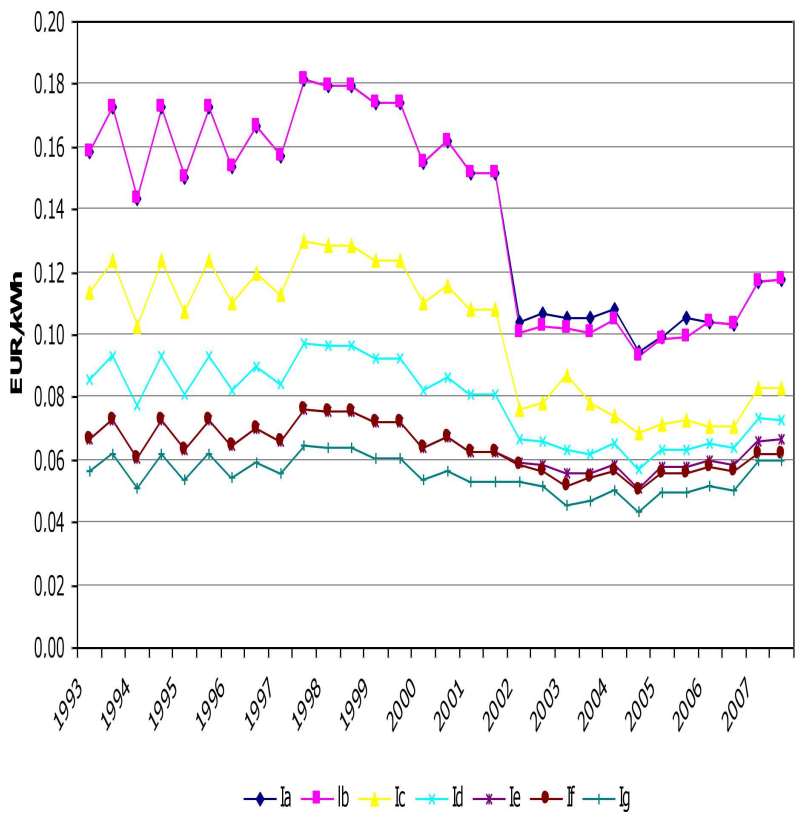

Fig. 2. Real prices of electrical energy for consumer groups of electrical energy use in industry in Slovenia, 1993-2007 (2003 base prices). Source: Authors' calculations from the data obtained from SORS [11] and Ministry of Infrastructure [14].

Since 2009, real prices of electrical energy for industrial users have started to decline a slightly below levels they were in 2005. This implies that the market liberalisation has created competitive pressures on real price declines not only initially, but also later after upward adjustment with a steady increase in real price up to 2009 and then declines. As can be seen from Fig. 3, there are some differences in levels and to a lesser extent in evolution in development of real prices of electrical energy for different consumer groups of electrical energy in industry in Slovenia. Finally, during the 2005-2015 period, real prices of electrical energy in industry in Slovenia have increased a slightly or are at similar levels for all consumer groups of electricity users. 
Management and Production Engineering Review

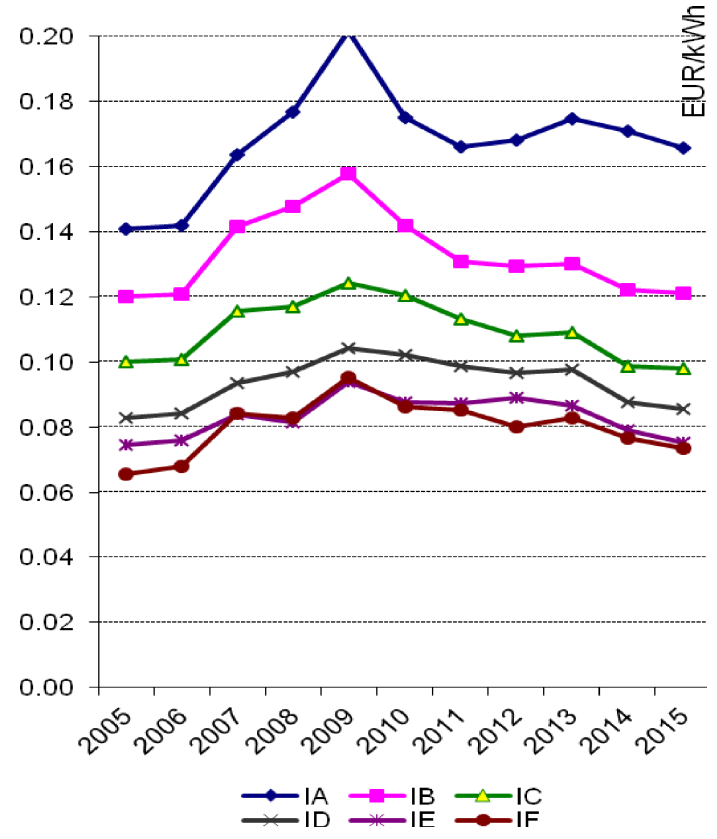

Fig. 3. Real prices of electrical energy for consumer groups of electrical energy use in industry in Slovenia, 2005-2015 (2010 base prices). Source: Authors' calculations from the data obtained from SORS (2016) and Ministry of Infrastructure (2016).

\section{Structure of electricity prices in industry}

We analyse the structure of electricity price developments for industrial users. The electricity price for industry consists from three main components: (1) the share for purchase electricity by electricity distribution enterprise from electricity producer that is formed at liberalized electricity market; (2) the share paid by electricity distribution enterprise for regulated infrastructure for the use of electricity network grids; and (3) the mandatory share for the state charges in the sale of electricity for duty, excise duty and value-added tax.

First, we present the structure of electricity price for industry for the consumer group IA during the first five-years, which followed the market deregulation and price liberalisation for industry since the mid-2004. The share for purchase electricity by electricity distribution enterprise from electricity producer increased between 2005 and 2008 (Table 2). During the same period and for the same consumer group IA in industry, the share paid by electricity distribution enterprise for the use of electricity network grids declined, while the share paid to the state budget for taxes and different duties increased.
Table 2

Structure of electricity price in industry for consumer group IA (in \%).

\begin{tabular}{c|c|c|c|c|c}
\hline & Energy & $\begin{array}{c}\text { Electricity } \\
\text { network }\end{array}$ & Taxes & $\begin{array}{c}\text { Excise } \\
\text { tax }\end{array}$ & $\begin{array}{c}\text { Value-added } \\
\text { tax }\end{array}$ \\
\hline 2005 & 43.25 & 35.75 & 4.33 & 0.00 & 16.67 \\
\hline 2006 & 42.66 & 36.33 & 4.34 & 0.00 & 16.67 \\
\hline 2007 & 47.26 & 31.86 & 3.94 & 0.27 & 16.67 \\
\hline 2008 & 52.76 & 28.28 & 2.00 & 0.29 & 16.67 \\
\hline 2009 & 50.44 & 28.29 & 4.36 & 0.25 & 16.67 \\
\hline
\end{tabular}

Source: Own calculations on the basis of data obtained from Ministry of Infrastructure (2016).

Second, we present the structure of electricity price for industry as a whole with the price pick in 2009 and gradual decline and price stabilization, which has followed. Changes in the structure of electricity price for industry between 2009 and 2015 can be seen in Table 3 for Slovenia as a whole (I - the Slovenian average of all prices for industry). Differences are in the structure of prices: the share has decreased for purchase electricity by electricity distribution enterprise and to a lesser extent for use of grids, but increased for taxes with VAT.

Table 3

Structure of electricity price in industry for consumer group I (in \%).

\begin{tabular}{c|c|c|c}
\hline & Electrical energy & Use of grids & Taxes, VAT \\
\hline 2009 & 59.91 & 19.55 & 20.55 \\
\hline 2014 & 49.78 & 21.77 & 28.45 \\
\hline 2015 & 51.27 & 18.78 & 29.95 \\
\hline
\end{tabular}

Source: Own calculations on the basis of data obtained from Ministry of Infrastructure (2016).

\section{Use of electricity network grids}

We can see that the price paid by electricity distribution enterprise for use of electricity network grids for different consumer groups per MWh varies considerably (Fig. 4). The highest is for the IA electricity user group in industry, while the lowest for the IF electricity user group in industry. These results indicate the importance of the economies of scale. The average price paid by electricity distribution enterprise for use of electricity network grids per MWh was the lowest for the largest IF electricity user group in industry and the highest for the smallest IA electricity user group in industry.

\section{Taxes and duties paid to state budget}

Moreover, taxes, excise taxes and value-added tax for different consumer groups of electrical energy use in industry have increased over time (Fig. 5). The 
lowest level and increase is seen in the case of the IF consumer group of electrical energy use in industry and the highest level and increase is seen in the case of IA consumer group of electrical energy use in industry.

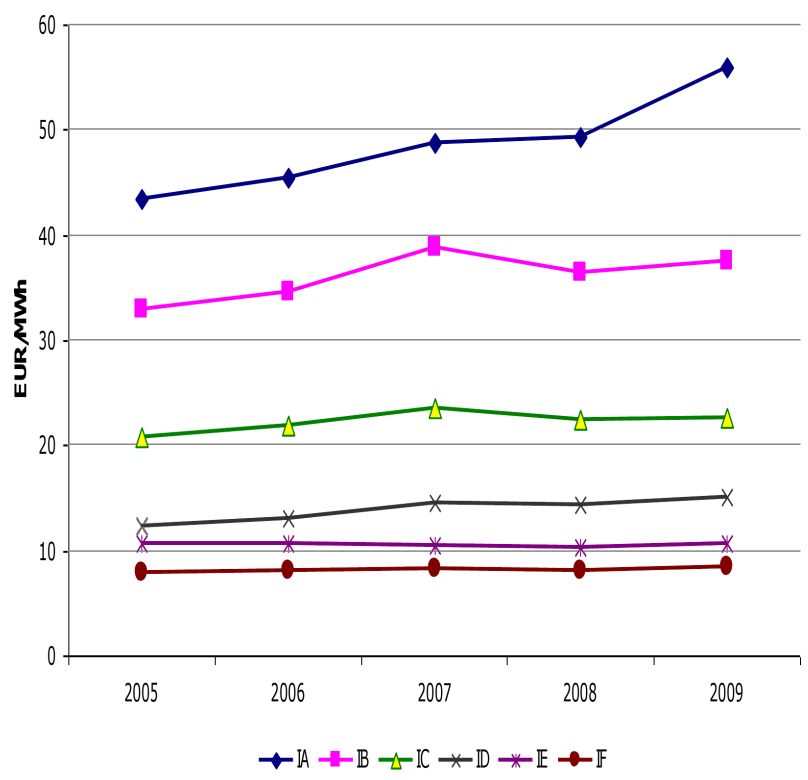

Fig. 4. Price paid by electricity distribution enterprise for use of electricity network grids for different consumer groups of electrical energy in industry in Slovenia, 20052009. Source: Own calculations on the basis of $[11,14]$.

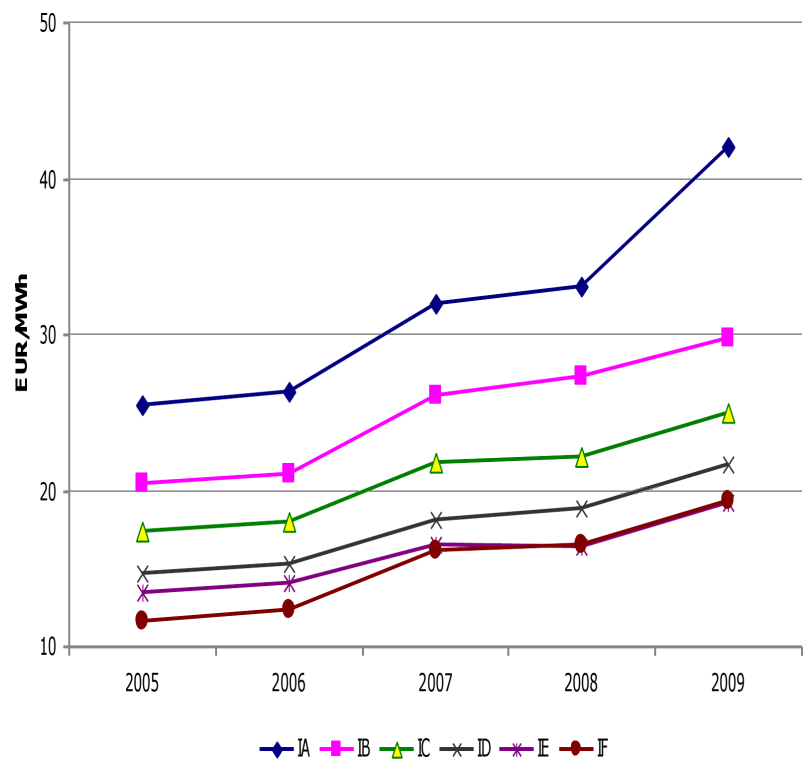

Fig. 5. Taxes, excise taxes and value-added tax for different consumer groups of electrical energy use in industry in Slovenia, 2005-2009. Source: Own calculations on the basis of [14].

\section{Regression analysis}

Consumption of electrical energy for industry on middle voltage $\left(D_{i-M V}\right)$ as dependent variable is explained by the following explanatory variables: real gross domestic product $(G D P)$, real price of electrical energy for the analysed industrial users at the middle voltage $(P I d)$, real price of electrical energy for other standard industrial users groups (PIg, PIf and $P I e$ ), and real prices for natural gas $(P n g)$ as substitute for electrical energy:

$$
D_{i-M V}=f(G D P, P I d, P I g, P I f, P I e),
$$

where $D_{i-M}$ - consumption of electrical energy by industrial users on the middle voltage $(1-35 \mathrm{kV})$ in period $t, G D P$ - real gross domestic product in period $t, P I d$ - real price of electrical energy for industrial users on middle voltage $1-35 \mathrm{kV}$ in period $t, P I g-$ average real price of electrical energy for standard user group for industry $I_{g}$ with annual consumption $24000 \mathrm{MWh}$ and power $4000 \mathrm{~kW}$ in period $t$, PIf - real price of electrical energy for standard user group for industry $I_{f}$ with annual consumption $10000 \mathrm{MWh}$ and power $2500 \mathrm{~kW}$ in period $t$, PIereal price of electrical energy for standard user group for industry $e$ with annual use $2000 \mathrm{MWh}$ and power $500 \mathrm{~kW}$, Png - real price of natural gas, dummy equal one for the deregulation period on the electricity market for industrial users and zero otherwise.

Firm-level data on electricity consumption in industry and prices of electrical energy are obtained from Electro Gorenjska. Data on prices of oil products in Slovenia are taken from website of oil company Petrol. All data on deflators (producer price index of industrial commodities and implicit deflator of GDP for the size of the economy) are obtained from SORS [11].

The electricity consumption in industry at the middle voltage $(1-36 \mathrm{kV})$ for the Electro Gorenjska is positively associated with the growth of GDP, but negatively associated with the real electricity prices (Table 4). This is consistent with theoretical expectations. The increase in GDP in Slovenia is in a positive association with the increase in use of electrical energy in industry. The coefficient of elasticity is between 0.56 and 0.69 . The association between the use of electrical energy in industry and the increase in GDP in Gorenjska region (GDP_G) is also positive and significant. The coefficient of elasticity is between 0.55 and 1.63 .

The increase in price of electrical energy for industrial user groups leads to reduction in demand for electrical energy for analyzed groups of users of electrical energy in industry. The regression coefficient of elasticity for PIe is between -0.36 and -0.39 . 
Management and Production Engineering Review

Table 4

Demand function of users of electrical energy in industry on middle voltage for Electro Gorenjska, 1993-2010.

\begin{tabular}{|c|c|c|c|c|c|c|c|c|}
\hline & $\ln ($ constant $)$ & $\ln (\mathrm{GDP})$ & $\ln \left(\mathrm{BDP}_{\mathrm{G}}\right)$ & $\ln (\mathrm{PId})$ & $\ln (\mathrm{PIe})$ & \multicolumn{2}{|c|}{$\mathrm{Adj}^{2}$} & $F$ \\
\hline $\ln \left(D_{i-M V}\right)$ & $\begin{array}{c}1.265 \\
(2.180) \\
\end{array}$ & $\begin{array}{c}0.562 \\
(9.792) \\
\end{array}$ & & $\begin{array}{c}-0.228 \\
(-2.244) \\
\end{array}$ & & & 0.850 & $\begin{array}{l}49.004 \\
{[0.000]}\end{array}$ \\
\hline $\ln \left(D_{i-M V}\right)$ & $\begin{array}{c}0.478 \\
(0.939)\end{array}$ & $\begin{array}{c}0.690 \\
(8.786)\end{array}$ & & & $\begin{array}{c}-0.361 \\
(-2.876)\end{array}$ & & 0.871 & $\begin{array}{l}58.142 \\
{[0.000]}\end{array}$ \\
\hline $\ln \left(D_{i-M V}\right)$ & $\begin{array}{c}1.808 \\
(1.216) \\
\end{array}$ & & $\begin{array}{c}0.545 \\
(2.847) \\
\end{array}$ & & & & 0.415 & $\begin{array}{c}8.103 \\
{[0.019]} \\
\end{array}$ \\
\hline $\ln \left(D_{i-M V}\right)$ & $\begin{array}{c}2.021 \\
(1.276) \\
\end{array}$ & & $\begin{array}{c}1.625 \\
(6.684) \\
\end{array}$ & & $\begin{array}{c}-0.391 \\
(-4.914) \\
\end{array}$ & & 0.846 & $\begin{array}{l}25.768 \\
{[0.021]}\end{array}$ \\
\hline & & & & & $\ln \left(P_{n g_{-} I 3-I}\right)$ & $\ln \left(P_{n g_{-} I 2}\right)$ & $\mathrm{Adj}^{2}$ & $F$ \\
\hline $\ln \left(D_{i-M V}\right)$ & $\begin{array}{c}7.511 \\
(8.295)\end{array}$ & & & $\begin{array}{c}-0.429 \\
(-1.982)\end{array}$ & & $\begin{array}{c}0.178 \\
(2.816)\end{array}$ & 0.342 & $\begin{array}{c}4.901 \\
{[0.026]}\end{array}$ \\
\hline $\ln \left(D_{i-M V}\right)$ & $\begin{array}{r}7.648 \\
(8.507) \\
\end{array}$ & & & $\begin{array}{c}-0.473 \\
(-2.181) \\
\end{array}$ & $\begin{array}{c}0.211 \\
(2.920) \\
\end{array}$ & & 0.360 & $\begin{array}{c}5.228 \\
{[0.022]} \\
\end{array}$ \\
\hline & & & & & $\ln$ (PIf) & $\ln ($ dummy $)$ & $\mathrm{Adj}^{2}$ & $F$ \\
\hline $\ln \left(D_{i-M V}\right)$ & $\begin{array}{c}0.587 \\
(0.377) \\
\end{array}$ & & $\begin{array}{c}0.937 \\
(3.725) \\
\end{array}$ & $\begin{array}{c}-0.425 \\
(-2.068) \\
\end{array}$ & & $\begin{array}{c}-0.079 \\
(-1.218) \\
\end{array}$ & 0.553 & $\begin{array}{c}5.124 \\
{[0.035]}\end{array}$ \\
\hline $\ln \left(D_{i-M V}\right)$ & $\begin{array}{c}1.268 \\
(0.978)\end{array}$ & & $\begin{array}{c}0.838 \\
(4.517)\end{array}$ & & $\begin{array}{c}-0.406 \\
(-2.933)\end{array}$ & $\begin{array}{c}-0.077 \\
(-1.414)\end{array}$ & 0.677 & $\begin{array}{c}7.985 \\
{[0.012]}\end{array}$ \\
\hline
\end{tabular}

* Dependent variable: use of electrical energy in industry at the middle voltage power $\left(D_{i-M V}\right)$, ln - natural logarithm,

$t$-statistic in the brackets, $F-F$-test with p-values in the brackets.

Consumption of electrical energy in industry is also inversely associated with price of electrical energy for standard user group PId. The coefficient of elasticity is between -0.23 and -0.43 .

We have also estimated possible substitution effect between electrical energy consumption in industry and consumption of natural gas in industry. The significant positive regression coefficient confirms that electrical energy and natural gas are substitutes in the Slovenian industry. The cross price elasticity is estimated between 0.18 and 0.21 indicating that the increase of price for natural gas by $1 \%$ increases consumption of electricity energy in industry between 0.18 and $0.21 \%$, ceteris paribus.

Liberalisation of electricity market for industry is negatively associated with electricity use in industry in Slovenia. The pressures for more rational use of electricity in industrial enterprises can be related also to some other factors such as competitive pressures on industrial enterprises output markets, which have created pressures for costs reductions, including for use of electrical energy.

\section{Conclusions}

The significant contribution of the research for the literature is the unique analysis of the market deregulation and price liberalization processes in the Slovenian electricity market for industry. The rele- vance of the results and their implications in the case of market structures and electricity prices for industry and determinants of demand for electricity in industry in Slovenia are particularly important for industrial organization, management and production engineering. While the empirical analysis is based on the Slovenian data sample, its implications with possible comparisons with other countries in the Central and South-Eastern European countries are of broader relevance beyond the Slovenian country example.

The starting point of the analyses has been the evolution in developments of real electricity prices for industry and the structure of electricity prices for industrial users in Slovenia. The market deregulation and electricity price liberalization have encouraged developments of competitive supply, which has not been a linear process, which is still ongoing. The competitive price supply of electrical energy depends on main elements in the structure of price such as for use of electricity network grids and taxes to the state budget. The increased competition has created pressures for the reduction of electricity distribution margin by the electricity suppliers.

The electricity price structure for different electricity consumer groups in industry has explored volatilities over time. This indicates that these price structures are not fixed, but are flexible and have changing over time. The share of costs for use of electricity network grids has reduced and thus the price 
for use of electricity distribution network grids has oscillated with a slight decline. The expenses paid by electricity distribution enterprise for different taxes and the share of different taxes in the price structure have increased. The real price paid by electro distribution enterprise for purchased electrical energy and thus the share of costs for purchased electricity by electricity distribution enterprise for its supply to industry has first increased, but then declined.

The real price of electrical energy for industrial users in Slovenia has increased during the period 2005-2009, and has declined since then. However, this has varied by different consumer groups of electricity users in industry. The reduced differentials between final price of electrical energy for consumers of electrical energy in industry and purchased price for electrical energy paid by distribution enterprise as suppliers of electrical energy to final consumer (enterprises) in industry indicates reduction of electricity distribution margin as a possible consequence of increased market competition.

The econometric part has investigated drivers of electrical energy consumption in industry in Slovenia. The regression analysis has confirmed the most important determinants of electrical energy consumption in industry. The results are consistent with theoretical expectations. The amount of electricity consumption in industry is positively associated with real GDP (positive income elasticity) and natural gas prices in the industry (positive cross price elasticity as substitute for electrical energy), but the electricity consumption in industry is negatively associated with the electricity prices for industry (negative direct price elasticity). The negative association is also between the electrical energy consumption in industry and the electricity market deregulation, which can be explained by more efficient electricity use in industry. This issue on efficiency of electricity use in industry is also an issue for further research.

\section{References}

[1] Papler D., Bojnec Š., The importance of management in the deregulated retail electricity distribution market in Slovenia [in Slovenia: Pomen managementa na dereguliranem maloprodajnem trgu električne energije $v$ Sloveniji], Management, 1, 2, 115129, 2006.

[2] Papler D., Bojnec Š., Electricity supply management for enterprises in Slovenia, International Journal of Management and Enterprise Development, 4, 4, 403-414, 2007.
[3] Papler D., Bojnec Š., Determinants of costs and prices for electricity supply in Slovenia, Eastern European Economics, 50, 1, 65-77, 2012.

[4] Pollitt M., Evaluating the evidence on electricity reform: lessons for the South East Europe market, London: ESRC Electricity Policy Research Group and Judge Business School, University of Cambridge, 2007.

[5] Bojnec Š., Papler D., Segmentation of electricity market for households in Slovenia, Chinese Business Review, 9, 7, 1-10, 2010.

[6] Ministry of Economy, Consumption of electrical energy in industry by size groups in 2007 and 2008, Ljubljana: Ministry of Economy - Directorate for Energy, 2009.

[7] Tooraj J., Pollitt M., Benchmarking and regulation: an international electricity experience, Utilities Policy, 9, 3, 107-130, 2000.

[8] Directive 2008/92/ES of European Parliament on Common Procedure of Community for Greater Transparency of Natural Gas and Electrical Energy [Direktiva 2008/92/ES Evropskega parlamenta o enotnem postopku Skupnosti za večjo preglednost cen plina in električne energije], (Ur. 1. EU L 298).

[9] Kachigan S.K., Multivariate statistical analysis: a conceptual introduction, New York: Radius Press, 1991.

[10] Norušis M.J., SPSS 11.0 Guide to Data Analysis, Upper Saddle River (N.J.): Prentice Hall, 2002.

[11] SORS, Data Portal SI-STAT, Environment and Natural Resources, Energy, Prices of Energy Products, Ljubljana: Statistical Office of the Republic of Slovenia, 2016. http://pxweb.stat.si/pxweb/Database/Okolje/18_energetika/02_18175_cene_energentov/02_18175_cene_energentov.asp (15 April 2016).

[12] Eurostat, Prices of electrical energy, Luxembourg: Eurostat, 2016. http://ec.europa.eu/eurostat/web/energy/data/database (28 May 2016).

[13] Directive of Council (EGS) 90/377/EEC on transparency of prices for natural gas and electrical energy [Direktiva Sveta (EGS) 90/377/EEC o preglednosti cen plina in električne energije].

[14] Ministry of Infrastructure, Portal Energy, Statistics, Electrical Energy - Quantities, Ljubljana: Ministry of Infrastructure - Directorate for Energy, 2016. http://www.energetika-portal.si/statistika/ (15 April 2016). 